ment of fever cases in the general wards, and separation of them into distinct wards, allowing that on this subject the opinions of competent anthorities differ. But I think there can be no question in the mind of anyone who has really studied the matter, that if fever is to be treated in distinct wards, such wards should be, if not in a different building, at any rate completely detached from the general hospital; that there should be no access from one part to the other unless by a door, of which the medical officer should keep the key, and always turn it on going out and coming in ; and after coming from the fever hospital he should be furbidden to go into the general hospital for a certain time. But a much more satisfactory plan, if there are special fever wards, is to have them in a separate building, and, I should be disposed to add, served by a separate staff both of nurses and medical officers.

The discrepancy, then, between our Report and that of the committee to which you refer did not proceed from negligence or ignorance of the facts on our part, but is a case of difference of opinion. I am quite ready to allow that the opinion of the local committee, who have such far superior opportunities of investigating the details, is probably the correct one; yet it would have been gatisfactory to have been assured that they had duly considered the effect of the arrangements to which I have referred.

Allow toe to add a few more words about another of the opinions cited in your paper of the 3rd inst., which I find has been somewhat misunderstood. You quote us, quite correctly, as saying that "allowing that each ward is healthy, and that say 30 patients can bo safely placed in the same ward, we see no reason to doubt that it is just as safe to put 100 wards together, and accommodate 3000 patients in the same hospital." We are not here recommending the construction of such vast establishments. Wo do not mean to deny that it would be difificult to construct a building which could contain 100 wards of this size, all of which should be well ventilated; that when constracted, so large an establishment would be very difficult of management and superintendence; that it would be too large for the purposes of a medical school, and beyond the wants of any urban population. But there are many exigencies of military service in which it might be most desirable to establish one very large lospital in place of several small ones; and in such cases we say that all present experience tends to show that the essential question in hospital salubrity is, whether each ward is well ventilated, and, ahove all, not overcrowded, particularly with infections cases. Take this very example of Dundee, and compare it with those of our metro. politan hospitals. In the latter, all cases of fever are freely received, but attention is paid to this point-that they are never accumulated in any one ward in such numbers as to make that ward unsafe for the treatment of other cases. This plan has been pursued for centuries, as far as I know, at St. Bartholomew's, and certainly for upwards of a century at most of our large London hospitals. No deaths of three or four honse-surgeons in succession, no great disasters to the patients, are ever heard of, unless the cantion as to accumulation of cases is neglected. Then, as happened at St. Bartholomew's some years ago, when a great number of cases of typhus were put together into a single ward, the case counes to resemble that of Dundee, and the same results follow. In the instance $I$ am referring to at St. Bartholomew's, typhus began to spread in the building, and it was thought necessary for a time to refuse admittance to the disease. Bat if there are no single wards in which it is dangerous to treat ordinary cases, it seems to us, from what evidence we could find, that there is no sanitary risk in any possible aggregation of wards. If there are such dangerous, or let us call them infectious, wards, infection is pretty sure to be carried to other parts of the building. This your reviewer seems to regard as incompatible with our assertion that if the building is well ventilated there is no evidence that any interchange of atmosphere takes place between the wards. But the eccentric way in which cases break out in the building, and the fact that it is always the nurses and housesurgeons who seem first affected, render it, to say the leas', equally probable that the infection is conveyed by fomites. I could hardly have orerlorked the sad case of Dundee; for when I went there the house-surgeon, a man well known over all that part of Scotlund for his zaal and promise, was lying lead, and his sucnessor. who showed me over the hospital, was struck down and died a few weeks afterwards. Bat surely, in the case of these poor young men. it is hardly necessary to sugrest that infecion was carried down long corridors and up two pair of stairs to their d welling rooms, when perhaps half their working day had been spent in the fever wards. The more this question is aiscussed, the more clear I be? become that in no general hospital should there be any ward in which general cases cannot safely be treated. Whether fevers should be treated in detached buildings or no is a very difficul t question, but it is one, I think, of subordinate importance, provided it be understood that no hospital should exist without provision for the treatment of all cases, infectious or otherwise. It is the scandal and reproach of our Finglish hospital system that this, instead of being the universal rule (as it is in Scotland), is the rare exception at our provincial infirmaries.

I am, Sir, yours \&c.,

Queen-street, Mayfair, Dec. 7th, 1861 . T. Hownts, M. A. Cantab.

\section{DR. MURCHISON AND DR. BUDD ON FEVER FROVI SEWAGE POISON.}

\section{To the Editor of The LANCET.}

SIR,-Dr. William Budd, of Bristol, has recently called my attention to the omission of a single word from a quotation in my work on "Fevers," published in 1862, which, in his opinion, materially alters the meaning that he intended to convey, and which I beg that you will give we an opportunity of at once correcting. The quotation is from a paper of Dr. Budd's in The Laxcer for October 29th, 1859 (p. 432), and occurs in a footnote at page 449 of my work. The footnote has reference to the following passage in the text of my book :

"On the other hand, Dr. Budd records three instances, from which he argues that sewers merely transmit the poison, in consequence of receiving the excreta of a diseased intestine. In all of these instances, the fever evidently arose from air or water tainted with se wage; but it is not shown that the sewage in any of the cases had first become contaminated with the excreta of a person suffering from enteric fever. The necessary link in the evidence, viz., the introduction of the poison, is wanting." (Murchison on Fevers, 1862, pp. 449, 449.)

Two of the three instances referred to occurred at Abbots ham-place and Richmond-terrace, Clifton. The footnote relates to the outbreak in Abbotsham-place, and is as follows :-

"In one of the instances, it is stated, that a few days before the water of a certain well was discovesed to be contaminated with sewage, there was a single case of fever in an adjoining house. But it is not shown that this patient contracted the disease elsewhere than in the house in question, or that diarrhcea had occurred before the patient in the next house began to be ill. Dr. Budd remarks :--"Whether or not this case was the source of the specific poison, from which the others sprang, we need not inquire.' It appears to me, that he has omitted to place the key stone in the arch of his argument." (Murchison on Fevers, 18b2, p. 449, footnote.)

The original, from which the quotation is taken, runs thus :-

"Whether or not this case was the source of the specific poison, from which the others sprang, we need not now in. quire." (Budd, The Lancet, Oct. 29, 1859, p. 432.)

I was not aware of the omission of the monosyllabic word "now" before "inquire," until Dr. Budd wrote to me about it. The omission was purely accidental, and I regret its occurrence.

Dr. Budd has also informed me that he cited the outbreak at Abbotsham-place merely as evidence that intestinal fever may be caused by a poison which sometimes exists in sewage, and not to show that the poison in the sewage was derived from the stools of an infected person. He, therefore, objects that the two sentences which, in his paper, immediately follow the word "inquire," are not included in my quotation, on the ground that they would have rendered the commentary in my footnote impossible. The two sentences are as follows :-

"All that I have now in view is to cite evidence to show that intestinal fever may be actually caused by a poison which sometimes exists in sewage. For this the facts that follow are pretty decisive."

I append another passage from a subsequent part of the same paper by Dr. Budd, to which, and not to the two sentences abrve quoted, the commente, both in the text and footnote of my work, refer :-

"'The tacts with which my last communication closed are conclusive as to the point to which they relate.

"There are few things in the history of disease so sure as the fact that, under circumstances which are of no uncommon occurrence, the excreta which the sewer receives from the human intesine may become the cause of intestingl fever. The 
proof on which the inference rests is so clear and precise as to leave no room to the severest scepticism to interpose a single doubt.

"The Abbotsham place and Richmond terrace outbreaks further show that these excreta rroduce this effect, not by a vague or general mode of action, as cold and damp, for iustance, may give pleurisy, bronchitis, or rhenmatism, as the case may be. but by actually furnishing the specifie poison which is the physical cause of the fever, as much as the marsh miasin furnishes the poison which gives the ague, or-to take a still stronger illus. tration-as much as, in the old practice of inoculation, the lancet furrished the specific poison which gave the small-pox." (The Larcet, Nov, 5, 1859, p. 458.)

It was my intention to correct the inadvertent omission of the word "now" in the earliest re impression of my work : on reflection, I have thought it best to do so without further delay, But as regards the tenor of the argument in the foot. note and text to which it refers, I see nothing to alter or amend. I am, Sir, your obedient servant,

Charles Morchison, M. D.

Wimpole-street, Dec. 17th, 1864

\section{THE LAST INDIAN MEDICAL WARRANT.}

\section{To the Editor of THe LaNCET.}

S1R,-I have attentively perused Sir Charles Wood's despatch of the 7th November, 1864, on the subject of the Reorganization of the Indian Medical Service, published in THE LANCET of the 26th ultimo. I am convinced, after a careful analysis of the provisions of the said despatch, that the apparent increase of pay in para. 28 is purely mythological. The ingenuity of the financial concoctors of this scheme has been exerted in lopping off the most important prize appointments, and in re-distributing the emoluments accruing therefrom among the assistantsurgeons of over five and under ten years' service. By this scheme all the lucrative European infantry and artillery charges are to be transferred to the Queen's service. To the present constituents of the service this serious loss will be regarded as an insuperable calamity boih from a pecuniary and professional point of view. To the loss of these most valuable aud valued appointments must be added the abolition of head-money for extra charges; the surgeon's and assistant surgeon's staff allowance, amounting to $300 \mathrm{rs}$. and $168 \mathrm{rs}$. per mensem for the medical charge of regiments, \&c.; of the allowance of $100 \mathrm{rs}$ and $30 \mathrm{rs}$. per mensein for charge of divisional and brigade staffs respectively. In fact, all those contingent aids which, with the pay proper, used to make the pay of the whole service amount to more than it will do nnder the new scheme, have been done sway with. It is apparent, therefore, that the pecuniary position of the Indian medical officer has not been improved.

By the despatch of the $16 \mathrm{th}$ May, Sir Charles Wood practically reduced the pay and allowances of the majority of the surgeons and assistant-surgeons, thus infringing-broadly, openly, and boldly, in the face of the British people-the parliamentary guarantee held ont in Henley's clanse. Doubtiless, the letter No. 2t2, of the $29 \mathrm{th}$ June, from the Government of India, alluded to in the first paragraph of Sir Charles Wood's last despatch, pointed out to that official the breach of faith that had been committed by him with the Indian medical service. To rectify this egregious blunder, and to make the pay of the execntive ranks amount to about the same as the aggregate income derived from all sources of emolument uader the old system, the scale of pay in para. 28 of the despatch of the 7th November was framed.

I maintain that, with the exception of the assistant surgeons after five years' servize, there has been no augmentation of pay conceded to any member of the service. And even with these officers the small increase-derived from the projected abolition of some of the bighest prize appointments in the Indian medical service--is confined to the next five years of service, inasmuch as after the tenth year of service the headmoney and full staff allowance would generally have brought in as much or more than the $600 \mathrm{rs}$. now allowed. The con. solidated pay allowed to surgeon-majors cannot surely be viewed as anything like compensation for the fatal loss of European regiments and artillery brigades which are now to be given over to the Queen's medical officers.

The nuemployed pay scale is an improvement. Practically it will not prove so very beneficial, as, from the manner in which the nedical service is always under officered, medical officers are seldom unemployed. On the contrary, nearly every officer fit for duty has extra charges of some kind or other, for which under the old system he receives extra pay. He will still have all this extra work imposed upon him, withont de. riving any additional emolument for the same-a hard and un. reasonable condition, which I regard as fatal to the favourable reception of the scheme under review.

The intentions of Sir Charles Wood regarding the administrative rank are fore shadowed in paragraphs 14,15 , and 16 of the despatch. Here we have initiated a movement which is siguificant of serious mischief to the Indian medical service, No mention is made in any part of the despatch of the three principal inspector generalships. Are these prizes-amounting to $£ 3600$ per annum in Bengal, $£ 3360$ in Madras, and $£ 3000$ in Bombay-to be abolished? Again, are w'e not justified in inferring that one of the inspector-generalships in Bengal, worth $£ 2400$, and several of the deputy inspector-generalships in Bengal, Madras, and Bombay, each worth $£ 2000$ per annam, are to be taken a way from the local service? Is it not in this way that Sir Charles Wood considers that the expense, which is the only objection to the new double staff, "will, on a readjustment of the local department of inspection, with a view of meeting the altered condition of the service, be found susceptible of considerable reduction"? Now the entire loss of this considerable reduction will fall on the loval service alone.

Sir Charles Wood reiterates the insult to the medical service in India, contained in the despatch of the 16th of May, in giving to the executive officers merely the pay of their rank, or the same pay as they drew before in another shape. The medical officer is henceforth to be the only servant in the em. ploy of the Government in India who is to have the pay of his rank without any staff allowance for holding most responsible charges.

How different it is with the officers of the military staff corps may be seen from the following statement:-

\begin{tabular}{|c|c|c|c|c|c|c|}
\hline $\begin{array}{l}\text { ient.-Col, as Commandant } 1 \\
\text { urg.-Maj., as Lient.-Col. }\end{array}$ & $\begin{array}{l}\text { Indiar } \\
\text { pay, } \\
\mathrm{R}_{.} \\
1032 \\
1000\end{array}$ & $\begin{array}{l}u \\
4 . \\
4 \\
0\end{array}$ & $\cdots$ & $\begin{array}{c}\text { Staff } \\
\text { lowarce } \\
\text { R. } \\
600 \\
-\end{array}$ & $\begin{array}{l}\cdots \\
\cdots\end{array}$ & $\begin{array}{l}\text { Total. } \\
1632 \\
1000\end{array}$ \\
\hline $\begin{array}{l}\text { aj., as Sen. Wing Commdt. } \\
\text { arg., ranking as Major... }\end{array}$ & $\begin{array}{l}759 \\
800\end{array}$ & $\begin{array}{l}3 \\
0\end{array}$ & $\cdots$ & $\stackrel{270}{-}$ & $\begin{array}{l}\cdots \\
\cdots\end{array}$ & $\begin{array}{l}1059 \\
800^{*}\end{array}$ \\
\hline $\begin{array}{l}\text { apt., as Jun. Wing Commdt. } \\
\text { ssist. -Surg. above } 5 \text { years }\end{array}$ & $\begin{array}{l}415 \\
600\end{array}$ & $\begin{array}{l}6 \\
0\end{array}$ & $\begin{array}{l}\cdots \\
\cdots\end{array}$ & $\begin{array}{c}230 \\
-\end{array}$ & $\begin{array}{l}\cdots \\
\cdots\end{array}$ & $\begin{array}{l}645 \\
600\end{array}$ \\
\hline $\begin{array}{l}\text { eut., acting as Adjutant } \\
\text { ssist. Surg. under } 5 \text { years }\end{array}$ & $\begin{array}{l}256 \\
450\end{array}$ & $\begin{array}{r}10 \\
0\end{array}$ & $\ldots$ & 200 & $\begin{array}{l}\cdots \\
\cdots\end{array}$ & $\begin{array}{l}456 \\
450\end{array}$ \\
\hline
\end{tabular}

It is under the well-educater and high-minded officers of the military staff corps that medical officers in the Indian service will be called upon to serve. Their constant sense of humilia. tion, caused by the unjust distinctions figured in the above tabular statement, can be better imagined than described.

In this communication, which has already grown too lengthy, I bave only referred to the vital point of pay. I have shown sufficient to convince anyone that whilst Sir Charles Wood's scheme designs the lopping off of the highest prize appointments in the Indian service, he merely gives the remaining officers the same pay as they drew before, or as near an approximation to this as possible. Instead of giving the pay from several sources, he consolidates all the items in to one payment, which may be called, for convenience, the pay of the rank the officer holds. The only exception is the assistant-surgeon above five years' service.

I entirely fail to perceive how the soheme is to entail a heavy expense upon the State, or how it "improves the condition and prospects of the medical service in India ;" nor can I conceive it possible that " the result will be at.once to diffuse a spirit of satisfaction and contentment amongst the officers now in the service, and to secure for the future a certain supply of medical officers of good position, liberal $f$ ducation, and professional ability for her Majesty's service in India."

December 5th, $186 \pm$. I am, Sir, your obedient servant,

INDOPHILEs.

\section{THE JOURNAL OF THE ASSOCIATION. \\ To the Editor of THX LANOET.}

SIR,-A short time since, I saw in the shop of a dealer in waste paper certainly not less than five years' accumulation of the above jonrnal, in wrappers, as issued from the office. A friend, also, who has been for many years a member of the Association, showed me a still larger number in exactly the same state, which he intended to dispose of in a similar man. 